\title{
Knowledge of Nursing Students about The Pre-Analytical Phase in Laboratory Analyses
}

\author{
Ümran Dal Yılmaz' (D, Tamer Yılmaz² (D) \\ 'Department of Nursing, Near East University Faculty of Nursing, Mersin, Turkey \\ ${ }^{2}$ Department of Basic Medical Sciences, Near East University Faculty of Dentistry, Mersin, Turkey
}

ORCID IDs of the authors: Ü.D.Y. 0000-0002-9482-6983; T.Y. 0000-0002-2386-5686.

Cite this article as: Dal Yılmaz Ü, Yılmaz T. Knowledge of Nursing Students about The Pre-Analytical Phase in Laboratory Analyses. Cyprus J Med Sci 2019; 4(2): II5-20.

\section{BACKGROUND/AIMS}

The aim of the present study was to determine the knowledge of the final year students of the nursing department about the preanalytical phase in the laboratory analysis.

\section{MATERIAL and METHODS}

This was a descriptive study conducted during the spring semester of 2017-2018 academic year. A total of I42 volunteer final year nursing department students were included in the study. A questionnaire was prepared by the researcher as a data collection tool.

\section{RESULTS}

Of the 142 final year nursing students, $93.7 \%$ responded correctly to the optimal blood-letting time for biochemical analysis. It was determined that $92.9 \%$ of the students correctly know blood-letting positions affect blood values or not, and $94.7 \%$ know the reason why blood-letting is performed in sitting or lying positions. Of the 142 students, $90.1 \%$ correctly identified the medium urine samples. It was determined that $96.4 \%$ of the students know within how many minutes at maximum blood samples should be sent to the laboratory after drawing

\section{CONCLUSION}

The study has provided evidence that the study course of "clinical biochemistry" included into the syllabus in the academic year of 2017-2018 for the first time increased the knowledge of the students about the collection, storage, and transfer of biochemistry laboratory specimens. The study concludes that it is advisable to include the study course of "clinical biochemistry"that predominantly handles the pre-analytical phase into the syllabi designed for nursing schools.

Keywords: Pre-analytical phase, biochemical analyses, laboratory evaluation, sample taking, student nurse

\section{INTRODUCTION}

Laboratory tests play an important role in the diagnosis and treatment of diseases. Almost $70 \%$ of all the decisions about the diagnosis, treatment, hospitalization, and discharge of patients are obtained based on the outcomes of laboratory tests. The test time consists of three phases in analyses: pre-analytical, analytical, and post-analytical phases. The correctness and reliability of a laboratory outcome depends on the quality of each of these phases. Errors may occur in any phase of an investigation. Pre-analytical phase accounts for $75 \%$ of all the errors occurring in laboratory tests; they can occur at any point in the process extending from the preparation of the patient, sample collection, transfer/transport, processing, storage to physiological effects, and/or interventional factors (I-7). Lad Hasit Dalpatbhai et al. (7) categorize the errors that occurred in the pre-analytical phase into four groups: (I) inappropriate form (28.24\%), (2) inappropriate specimen (3.52\%), (3) inappropriate transfer (22.16\%), and (4) inappropriate centrifuge (7.29\%). Since collection of blood specimen is the first step, any error made in this step would put the test results in jeopardy regardless of whether or not the tests have been correctly analyzed. Most of the analytical errors occur due to human factors and can be prevented by proper education and training. Healthcare professionals, including nurses, phlebotomists, personnel in laboratories, and transportation services, play an important role with respect to the emergence of analytical errors (6). Lichtinghagen (2016) underlines in his book entitled "Tips and Techniques in Pre-analytical" that the pre-analytical phase is the most import- 
ant factor in laboratory tests with respect to the correctness of tests. He also points out that nurses have great responsibilities in specimen collection (4). Previous research has provided evidence that training programs specifically designed for nurses do substantially reduce pre-analytical errors and have a positive effect on the quality of laboratory specimens. Knowledge is a powerful tool in healthcare, and a well-educated nurse can be the difference between a patient's life and death. Providing nurses the skills and tools they need to positively impact individual's lives is important (8-10).

In our previous study, it was determined that the students did not have information about obtaining, storing, and transferring biochemical laboratory samples (II). Within the concept of the present study, nursing students were provided training for 28 $\mathrm{h}$ before they begin their professional life with respect to biochemical analyses, such as appropriate specimen collection, appropriate storage of specimens, and transport to the laboratory, as a part of the responsibilities they would assume. The present study includes the results of the inquiry performed at the end of the training to control the information the students received. The aim of the present study was to see the results of our training.

\section{MATERIAL and METHODS}

This was a descriptive study conducted during the spring semester of the 2017-2018 academic year. A total of 142 volunteer final year nursing faculty students out of 160 were included in the study. As the results obtained in the study with the title "Determination of the nursing students' knowledge regarding the biochemical laboratory specimens," which was performed in the academic year of 2016-2017, to determine the responsibilities of nurses in the pre-analytical phase were insufficient (II), the course program of "Biochemistry" was added to the syllabus of the Faculty of Nursing of Near East University, and a new group of students were informed in a course of $2 \mathrm{~h}$ during the week for 14 weeks(February-June2018)regarding the evaluation of the results of the pre-analytical phase and the post-analysis results. To collect data, the question form was used as designed by the researchers for our previous study based on the models available in the literature (II), including the descriptive features of the students and the questions regarding biochemical analyses.

As a data collection tool, a questionnaire, which was prepared by the researcher in the line with the literature (1-12) and included "Descriptive characteristics of the students and information questions about the taking and transferring of the biochemistry laboratory samples," was used.

The questionnaire related to the descriptive characteristics of students was composed of four questions regarding age, gender, school graduated, and hometown. The questionnaire related to the biochemical analyses was composed of four parts. There are a total of 24 questions, including II questions about pre-sample taking in section I, 4 questions about the order of sample taking in section 2, 5 questions about sample taking in section 3 , and 4 questions about the evaluation of results in section 4. The questions were prepared as multiple choices, and their answers were evaluated as true and false. The questionnaire was applied to students in the class on June I, 2018. Students spend approximately $40 \mathrm{~min}$ to answer the questions.
Statistical Package for the Social Sciences (SPSS) package program, version 2 I (IBM Corp.; Armonk, NY, USA) was used for statistical analysis of the responses obtained from the data collection forms. Students' answers were evaluated as percentages as true and false.

Written permission was received from the Near East University Scientific Research and Ethics Committee (26.4.2018/565) to conduct the research. Verbal and written informed consents were obtained from the students before application of the questionnaire.

After completion of the study, the researcher gave a conference on biochemical analyses to complete the missing information, and the students were informed before graduation.

\section{RESULTS}

It was determined that $76.0 \%$ of the students were female, $50.6 \%$ were graduate of public high schools, $60.8 \%$ were Turkish nationals, and the average age was $23.27 \pm 1.13$ (22-28) years.

The tables describe the students' knowledge about the biochemical analyses.

As shown in Table I, 3.5\% of the students answered the information that should be in the laboratory sample request document, and $93.6 \%$ responded correctly to the optimal blood-letting time for biochemical analysis. It was determined that $92.9 \%$ of the students correctly know whether the sitting, lying, or on-foot blood-letting positions affect blood values or not, and $94.7 \%$ know the reason why blood-letting is performed in the sitting or lying positions. It was observed that $90.1 \%$ of the students correctly identified the medium urine sample, and $93.7 \%$ correctly understood the 24-hour urine collection practices.

It was reported that $88.0 \%$ of the students correctly answered the sample to be first taken from the patient during blood-letting, and 78.2\% correctly answered for which analyses the blood sample taken into purple-cover tube is used (Table 2).

As shown in Table 3, it was determined that $96.5 \%$ of the students know within how many minutes at maximum blood samples should be sent to the laboratory after drawing, and 2.8\% correctly know which values increase in case of delayed delivery of blood samples to the laboratory. They gave correct answers to the questions related to storage conditions of urine container as as $93.7 \%, 90.1 \%, 66.9 \%$, respectively.

It was determined that $96.4 \%$ of the students know the normal value of fasting blood glucose, $98.6 \%$ know the routine blood tests very frequently requested from the emergency patients, and $34.5 \%$ know which of the blood proteins increase much in acute infections (Table 4).

\section{DISCUSSION}

Erroneous results do not only lead to incorrect diagnoses but also affect the patients both materially and morally. As is known, the responsibility of collecting and labeling proper specimens for analysis in the pre-analytical phase and delivering them to the laboratory generally depends on the nurses $(12,13)$. 
Nurses need not be specialized in the technical details of laboratory analyses. However, knowledge about pre-analytical variables is important because it has a significant effect on the results of laboratory tests. Of the pre-analytical errors, $60 \%$ result from insufficient quantity of specimens and inappropriate specimen quality. Confusion about the process of blood sampling, errors in patient identification and preparation, faults at specimen collection device/container, and errors in processing the specimens ultimately jeopardize the laboratory results. Such errors can seriously affect the reliability of test results, also impacting the diagnosis and treatment process of the disease. As the specimens are collected by nurses, these errors can be rarely detected by laboratories. The "human factor" plays a role in concealing errors in an unrealistic way; however, recognizing and defining probable error fields through adequate trainings provided on a repetitive and continual basis can substantially reduce errors (14-18).

The steps of sample taking, labeling, preservation, and delivery to the laboratory should be followed carefully. The name and surname of the patient must be verified before obtaining any samples. The name, protocol number, department of the patient, and the date and time of sample taking should be labeled on the sample container. It is necessary that the requests are properly coded, and that sufficient samples are delivered to the laboratory.

In the previous study we performed to determine the responsibilities of nurses in the pre-analytical phase, few students (II.0\%) had complete knowledge about the information required on the specimen request form (II). The same rate was found to be $3.5 \%$ in the present study, leading to the conclusion that they do not learn here attentively enough (Table I). Special focus should be given to this matter in future courses.

Time of taking is important for blood components that undergo a significant diurnal variation and for controlling drug treatment. The time passing after drug administration affects the drug level $(12,19)$. In our previous study, the number of students who had correct knowledge about the most appropriate hour of blood sampling for biochemical analyses was the highest (83.9\%) as far as knowledge regarding the specimen pre-collection phase is concerned. As for answers about the most appropriate time for blood sampling in the present study, $93.6 \%$ of the students gave the correct answer (Table I). In our previous study, while the rate of correct answers about the appropriate time for blood sampling was $78 \%$, it was calculated to be $88 \%$ after the course. Aykal et al. (20) observed that an inadequate sample is found to be important among the rejection reasons of laboratory samples.

The rates of correct answers regarding blood specimens with anticoagulants and blood gases were $51.7 \%$ and $68.6 \%$, respectively. In the present study, the rate of correct answers regarding blood specimens with anticoagulants decreased to 40.1\% (Table 2), but that regarding blood gases increased to $97.1 \%$ (Table I).

The positioning of the patient is important during blood sampling. The patient should comfortably lie on his/ her back or sit for $15 \mathrm{~min}$ before blood-letting. Depending on the lying/sitting and on-foot position, there is a transition of body fluid between the cells at significant levels. The blood volume in a standing person is 600$700 \mathrm{~mL}$ less than that in a person lying. This situation shows a reduction of approximately $10 \%$ in blood volume. As a result of that, blood-letting is performed by lying or sitting positions, as signifi- cances are observed in the concentration of all proteins, including enzymes and protein hormones, calcium, bilirubin partially bound to proteins, and drugs bound to protein. Owing to postural effect, plasma proteins may be found to be higher in patients subject to on-foot blood-letting than in patients who sat and waited for 30 min. For this reason, the patients should be required to wait in a sitting position until his/her turn comes for blood-letting, and it should be ensured that blood-letting is certainly performed in the sitting position (19,21-23).

In our previous study, the rates of correct answers to our questions about patient positioning during the blood sampling process were $52.5 \%$ and $45.8 \%$, respectively. The present study performed after the course found a correct answer rate of $92.9 \%$ to our question whether blood sampling performed in the sitting, lying, or standing position has an effect on blood values and $94.7 \%$ to the question why blood sampling should be undertaken in the sitting or lying position. We are glad to report that our students have quite clearly understood this process with great importance in blood sampling.

Küme et al. (24) found that the majority of mistakes (73\%) occur during sample taking. The content of the first drawn blood

\begin{tabular}{|c|c|c|}
\hline \multirow[b]{2}{*}{ Questions related to pre-sample taking } & \multicolumn{2}{|c|}{ Correct answers } \\
\hline & $\mathbf{n}$ & $\%$ \\
\hline Sample used in the blood gases test & 138 & 97.1 \\
\hline $\begin{array}{l}\text { The reason why blood-letting is performed in } \\
\text { the sitting or lying positions }\end{array}$ & 134 & 94.7 \\
\hline $\begin{array}{l}\text { The optimal blood-letting time for biochemical } \\
\text { analysis }\end{array}$ & 133 & 93.7 \\
\hline Applications related to 24 -hour urine collection & 133 & 93.7 \\
\hline $\begin{array}{l}\text { Whether the sitting, lying, or on-foot blood-letting } \\
\text { positions affect blood values or not }\end{array}$ & 132 & 92.9 \\
\hline Definition of medium urine sample & 128 & 90.1 \\
\hline Definition of spot urine & 128 & 90.1 \\
\hline Proper blood sample taking & 125 & 88.0 \\
\hline $\begin{array}{l}\text { The most widely preferred vein in arterial } \\
\text { blood-letting }\end{array}$ & 109 & 76.8 \\
\hline $\begin{array}{l}\text { Finding in serum samples arising as a result of an } \\
\text { error in blood-letting timing }\end{array}$ & 17 & 11.9 \\
\hline $\begin{array}{l}\text { Information required in the laboratory sample } \\
\text { request document }\end{array}$ & 5 & 3.5 \\
\hline
\end{tabular}

TABLE 2. Knowledge of the student nurses about the order of sample taking $(n=142)$

Correct answers

Questions related to sample taking and order of taking

Sample to be first taken from the patient during blood-letting

For which analyses the blood sample taken into purple-cover tube is used

Which blood sample includes anticoagulant

n $\%$

What color blood tube has to be shaken by slowly turning upside-down following blood-letting

12588.0

III $\quad 78.2$

$95 \quad 66.9$

$57 \quad 40.1$ 
shows best the composition of the circulating blood. Therefore, the first sample obtained should be used for important tests in critical medical decisions, such as calcium. When the tourniquet is applied, the blood that is drawn later is the content in the small veins and capillaries. It significantly shows the effect of venous stasis. The first tube may show a $5 \%$ increase, whereas the third tube may show a $10 \%$ increase in protein. Concentrations of protein-bound compounds are also affected by stasis $(12,23,25)$.

Of the students who participated in our previous study, $22.0 \%$ gave the correct answer to the question about which specimen is to be obtained right at the beginning during the blood sampling process, and $45.8 \%$ to the question about which analyses are to be undertaken with the blood specimen taken into the tube with a violet lid (II). These rates increased to $88.0 \%$ and $78.2 \%$ after the course, respectively (Table 2 ). As full blood examination is needed for certain tests, such as hemogram, blood gas, ammonia, and lactate, the blood to be used for such tests is drawn into a tube containing an anticoagulant. Since the anticoagulant used affects certain tests, a tube proper for the parameter to be analyzed must be used. These error sources should be known, defined, and controlled to the extent possible. These points should especially be underlined in the training programs designed for students.

Our previous study found that the students had insufficient knowledge about urine sampling. Of the students, $57.1 \%$ correctly defined what clean-catch urine specimen is, and only $14.3 \%$ had correct knowledge about the practices regarding 24-hour urine specimen (II). These rates increased to $90.1 \%$ and $93.7 \%$ after the course, respectively (Table I).

The type of urine sample to be collected depends on the test to be performed. Generally, urine samples should be collected in a predetermined time period, such as $1,4,12$, and $24 \mathrm{~h}$. The first urine, which is obtained early in the morning with a clean and hungry stomach, is usually the most concentrated urine, and microscopic examination is preferred for identification of abnormal amounts of contents, such as protein, and for identification of compounds, such as human chorionic gonadotropin. The collection period of timed samples should be long enough to minimize the effect of short-term biological variations. The bladder should be emptied before the collection starts, and this urine should be discharged. Thereafter, all urines should be collected until the end of the time period. Patients should be informed by the nurse with regard to dietary and drug intake before urine collection is started to avoid interference with the compounds taken with the analytical transactions $(22,25,26)$.

The results about the correct answers of the students regarding urine sampling and storage conditions in our previous study were also not satisfactory (II). Of the students participating in that study, $50.8 \%$ correctly answered to our question about the preservative agents to be added to urine specimens, and $68.6 \%$ to our question about the storage conditions of urine container used for 24-hour urine specimens. These rates increased to $66.9 \%$ and $93.7 \%$ after the course, respectively (Table 3 ).

Küme et al. (24) found that the errors related to urine analysis among erroneous sample types are $8 \%$. Before starting the urine collection, suitable preservatives (e.g., $6 \mathrm{~N}$ hydrochloric acid) should be placed in the collection container to prevent degradation of the parameters to be analyzed. When the 24hour urine is collected, the bladder is emptied by first urinating in the morning, and then the entire urine during the day is poured into the collection container. On the next morning, the first urine is taken into the collection container and delivered to the laboratory as soon as possible. During the urine collection period, the collection container is stored in a cool place $(22,24-26)$.

Sharaki et al. (27) found that $87.84 \%$ of the errors in urine samples are in the pre-analytic stage and are particularly related to sample collection.

Errors can occur during specimen collection at hospitals, and $60 \%$ of the errors occurring in the pre-analytical phase are attributed to insufficient specimen quality or quantity. Therefore, nurses should be aware of pre-analytical errors and make efforts to reduce them.

For patient safety, it is necessary to know the sources of errors, to control them, and to increase the knowledge level of health professionals through in-service trainings. Nurses play an important role in collecting and handling blood specimens and providing information to patients prior to tests. For this reason, healthcare professionals should be very conscious of the effects of individual pre-analytical factors and their combinations on test results (28-32).

We asked the nursing student for information about the evaluation of some laboratory test results, such as; the normal value of fasting blood glucose (Table 4). Nurses are the ones who

\begin{tabular}{|c|c|c|}
\hline \multirow[b]{2}{*}{ Questions related to post-sample taking } & \multicolumn{2}{|c|}{ Correct answers } \\
\hline & $\mathbf{n}$ & $\%$ \\
\hline $\begin{array}{l}\text { Within how many minutes at maximum blood samples } \\
\text { should be sent to the laboratory after drawing }\end{array}$ & 137 & 96.5 \\
\hline $\begin{array}{l}\text { Condition of storage of the urine collection container } \\
\text { for } 24 \text {-hour urine collection duration }\end{array}$ & 133 & 93.7 \\
\hline $\begin{array}{l}\text { If the urine sample will not be analyzed promptly, } \\
\text { condition of storage after taking }\end{array}$ & 128 & 90.1 \\
\hline $\begin{array}{l}\text { If the urine sample will not be analyzed within } 2 \mathrm{~h} \text {, } \\
\text { the chemical protectors that have to be added into } \\
\text { the urine collection container }\end{array}$ & 95 & 66.9 \\
\hline $\begin{array}{l}\text { Which values increase in case of delayed delivery of } \\
\text { blood samples to the laboratory }\end{array}$ & 4 & 2.8 \\
\hline
\end{tabular}

TABLE 4. Knowledge of the student nurses about the evaluation of results $(n=142)$

Correct answers

Questions related to the evaluation of results

Routine blood tests very frequently requested from the emergency patients

Normal value of fasting blood glucose

n $\%$

Important indicators of the blood count results for bleeding patient

Which blood proteins significantly increase in acute infections
$140 \quad 98.6$

$137 \quad 96.4$

$72 \quad 50.7$

$49 \quad 34.5$ 
generally see the results of the tests requested from the inpatients. Therefore, it is very important in early intervention that the nurses realize abnormal laboratory results of patients and inform the physician. It is important for nursing students to have knowledge about laboratory results, especially critical values, by having the necessary training. Teaching some critical laboratory values in the education of nursing students will be useful in practice.

In conclusion, the study has provided evidence that the study course of "clinical biochemistry" included into the syllabus in the academic year of 2017-2018 for the first time increased the knowledge of the students about the collection, storage, and transfer of biochemistry laboratory specimens. The study results indicate that a program to be designed for nurses should especially focus on the pre-analytical phase. The information about the post-analytical phase can be learned in a short time beginning with the most important pieces of information. In conclusion, it is advisable to include the study course of "clinical biochemistry" that predominantly handles the pre-analytical phase into the syllabi designed for nursing schools.

Ethics Committee Approval: Ethics committee approval was received for this study from the Ethics Committee of Near East University School of medicine. (Approval Date: 26.09.2018, Approval Number: 565).

Informed Consent: Written informed consent was obtained from the patients who participated in this study.

Peer-review: Externally peer-reviewed.

Author contributions: Concept - Ü.D.Y., T.Y.; Design - T.Y., Ü.D.Y.; Supervision - T.Y., Ü.D.Y; Resource - T.Y., Ü.D.Y; Materials - Ü.D.Y., T.Y.; Data Collection and/or Processing - Ü.D.Y., T.Y.; Analysis and/or Interpretation - Ü.D.Y., T.Y.; Literature Search - T.Y., Ü.D.Y.; Writing - Ü.D.Y., T.Y.; Critical Reviews - Ü.D.Y., T.Y.

Acknowledgements: We would like to express my great, appreciation to nursing students for their participation in this research

Conflict of Interest: The authors have no conflicts of interest to declare.

Financial Disclosure: The authors declared that this study has received no financial support.

\section{REFERENCES}

I. Regan M, Forsman R. The impact of the laboratory on disease management. Dis Manag 2006; 9: 122-30. [CrossRef]

2. Hallworth MJ. The '70\% claim': what is the evidence base? Ann Clin Biochem 20ll; 48: 487-8. [CrossRef]

3. Veena Bhaskar S Gowda. Pre-analytical errors in clinical laboratory: Role of a nurse in reducing the same. 14th Surgical Nursing ¿ Nurse Education Conference. October I0-II, 2016, Kuala Lumpur, Malaysia.

4. Lichtinghagen R. Tips and techniques in preanalytics. Availabkr from: URL: https://dafxbb5uxjcds.cloudfront.net/fileadmin/ user_upload/99_Broschueren/Broschueren_neu_0l.2016/453_e_ TippsTricks_GB_Oll6.pdf. (Accessed: June 2018)

5. Boone DJ. Comment on Dr Houwen's paper 'Random errors in haematology tests.' Clin Lab Haematol 1990; 12 (Suppl I): 169-70.

6. 3. Sağlık Hizmetleri. Biyolojik Örnek Alma ve Nakli. Ankara 2015. Available from: URL: http://www.megep.meb.gov.tr/mte_program_modul/moduller/Biyolojik\%20\%C3\%96rnek\%20Alma\%20 ve\%20Nakli.pdf (Accessed: May 2018)
7. Lad HD, Rana NM, Chaudhari VS, Ramavataram DVSS. A study of preanalytical errors in a hospital based clinical biochemistry laboratory and recommendation of required corrective measures. Int $\mathrm{J}$ Clin Biochem Res 2016; 4: 380-6.

8. Al-Ghaithi H, Pathare A, Al-Mamari S, Villacrucis R, Fawaz N, Alkindi S. Impact of Educational Activities in Reducing Pre-Analytical Laboratory Errors. Sultan Qaboos Univ Med J 2017; 17: e309-13. [CrossRef]

9. Lillo R, Salinas M, Lopez-Garrigos M, Naranjo-Santana Y, Gutiérrez M, Marín MD, et al. Reducing preanalytical laboratory sample errors through educational and technological interventions. Clin Lab 2012; 58: 911-7.

10. Arslan FD, Karakoyun I, Basok BI, Aksit MZ, Celik E, Dogan K, Duman C. The Effects of Education and Training Given to Phlebotomists for Reducing Preanalytical Errors. J.Med. Biochem 2018; 37: 172-80. [CrossRef]

II. YIImaz T, Dal YIlmaz Ü. Determining knowledge of the nursing students about biochemistry laboratory. Turk J Biochem 2017; 43: 93-6. [CrossRef]

12. Wayne G. Nurses' Guide to Specimen Collection, Preparation, and Handling Procedures, 2015. Available from: URL: https://nurseslabs.com/nurses-guide-specimen-collection-preparation-handling-procedures/.

13. Birgili F, Aydın Ș. Examination of Negative SignSymptoms Seen During Bloodletting and the Level of Anxiety from Individuals which are Donating Blood. Hacettepe University Faculty of Health Sciences Journal 20II; 17-26.

14. Lippi G, Bassi A, Brocco G, Montagnana M, Salvagno GL, Guidi GC. Preanalytic error tracking in a laboratory medicine department: Results of alyear experience. Clin Chem 2006; 52: 1442-3. [CrossRef]

15. Li ppi G, Sal vagno GL, Mont agnana M, Franchini M, Guidi GC. Phlebotomy issues and quality improvement in results of laboratory testing. Clin Lab 2006; 52: 217-30.

16. Bologna LJ, Lind C, Riggs RC. Reducing major identification errors within a deployed phlebotomy process. Clin Leadersh Manag Rev 2002; 16: 22-6.

17. Bologna LJ, Mutter M. Life after phlebotomy deployment: Reducing major patient and specimen identification errors. J Healthc Inf Manag 2002; 16: 65-70.

18. Lippi G, Guidi GC. Risk management in the preanalytical phase of laboratory testing. Clin Chem Lab Med 2007; 45: 720-7. [CrossRef]

19. Akbay A, Öztaș Y, Bozdayı G. Klinik Laboratuvarda Temel Kavramlar. Ankara Üniversitesi Dikimevi Sağlık Hizmetleri Meslek Yüksekokulu Yayınları. Available from: URL: http://kitaplar.ankara.edu.tr/ dosyalar/pdf/037.pdf.

20. Aykal G, Yeğin A, Aydın Ö, Yılmaz N, Ellidağ HY. The impact of educational interventions on reducing the rejection ratesin the preanalytical phase. Turk J Biochem 2014; 39: 562-6. [CrossRef]

21. Dorotić A, Antončić D, Biljak VR, Nedić D, Beletić A. Hemolysis from a nurses' standpoint - survey from four Croatian hospitals. Biochem Med (Zagreb) 2015; 25: 393-400. [CrossRef]

22. Zhou F, Guo H, Hao Y, Tang L. The research on establishment of "clinical practice guide of blood specimen collection, preservation and delivery for clinical nurse": protocol description gstf. GSTF J Nurs Health Care 2015; 3: 179-84. [CrossRef]

23. Richard A. McPherson, Matthew R. Pincus. Henry's Clinical Diagnosis and Management by Laboratory Methods. 22ND edition, 20ll; E-Book. [CrossRef]

24. Küme T, Șișman A.R, Özkaya A, Çoker C. Preanalytical Errors of Specimens Sent from the Emergency Department to the Laboratory. Türk Klinik Biyokimya Derg 2009; 7: 49-55.

25. Young D. Conveying the importance of the preanalytical phase. Clin Chem Lab Med 2003; 4I: 884-7. [CrossRef]

26. Coșar A, Gültepe M. Biochemical Tests and Incorrect Applications. Türkiye Klinikleri J Fam Med-Special Topics 2013; 4: 102-6.

27. Sharaki O, Abouzeid A, Hossam N, Elsherif Y. Self assessment of pre, intra and post analytical errors of urine analysis in Clinical Chemistry Laboratory of Alexandria Main University Hospital. Saudi Journal for Health Sciences 2014; 2: 96-102. [CrossRef]

28. Plebani M. Errors in clinical laboratories or errors in laboratory medicine? Clin Chem Lab Med 2006; 44: 750-9. [CrossRef] 
29. Wallin O, Söderberg J, Guelpen B, Grankvist K. Patient-centred care-preanalytical factors demand attention: a questionnaire study of venous blood sampling and specimen handling. Scand J Clin Lab Invest 2007; 67: 836-47. [CrossRef]

30. Lippi G, Montagnana M, Giavarina D. National survey on the pre-analytical variability in a representative cohort of Italian laboratories. Clin Chem Lab Med 2006; 44: |49|-4.[CrossRef]
31. Hilborne LH, Lubin IM, Scheuner MT. The beginning of the second decade of the era of patient safiety: Implications and roles for the clinical laboratory and laboratory professionals. Clin Chim Acta 2009; 404: 24-7. [CrossRef]

32. Mäkitalo O, Liikanen E. Improving Quality at the Preanalytical Phase of Blood Sampling: Literature Review. IJBLS 20I3; I: I: 7-16. 